[Chem. Pharm. Bull.

36(10)4095-4102(1988)

\title{
Formation of Cyanide Ion or Cyanogen Chloride through the Cleavage of Aromatic Rings by Nitrous Acid or Chlorine. X. ${ }^{1)}$ Pathway of Cyanogen Chloride Formation in the Reactions of 1-Naphthol and 4-Phenylimidazole with Chloramine
}

\author{
TaKeshi OHya* and Saburo Kanno \\ Faculty of Pharmaceutical Sciences, Josai University, \\ 1-1, Keyakidai, Sakado, Saitama 350-02, Japan
}

(Received January 18, 1988)

\begin{abstract}
The pathway in the formation of cyanogen chloride from the reaction of 1-naphthol (1) and 4phenylimidazole with chloramine was investigated. The intermediates isolated in the reaction of 1naphthol (1) with chloramine were $N$-chloro-1,2-naphthoquinone 2 -imine (2) and $o$-carboxycinnamonitrile (6), the latter of which, liberating cyanogen chloride, was finally converted to phthalide-3-carboxylic acid (8). The products obtained in the reaction of 4-phenylimidazole (10) with chloramine were benzonitrile (14), benzoylformic acid (22) and benzoic acid (23) besides cyanogen chloride. Cyanogen chloride formed by the reaction of 4-methylimidazole with $\left[{ }^{15} \mathrm{~N}\right]-$ chloramine was $\mathrm{C}^{14} \mathrm{NCl}$. From these results the pathway of cyanogen chloride formation was elucidated.
\end{abstract}

Keywords cyanogen chloride; 1-naphthol; 4-phenylimidazole; histidine; chloramine; hypochlorous acid

\section{Introduction}

As is generally known, chloramine is widely generated as a by-product of the chlorination of public water and waste water, which commonly contain ammonium ion. ${ }^{2-4)}$ It is also generally accepted that phenolic compounds as a component of humic material and amino acids are often contained in natural water and waste water. ${ }^{5-9)}$

In the previous papers, ${ }^{10-13)}$ we reported that cyanogen chloride was formed by the reactions of aromatic compounds such as aromatic hydrocarbons, aromatic amines, phenolic compounds and aromatic amino acids with hypochlorous acid in the presence of ammonium ion in a neutral aqueous solution at room temperature and that the formation of cyanogen chloride was due to the cleavage of the aromatic rings by chloramine. We also reported that cyanogen chloride was formed during chlorination of raw water sampled at water treatment plants and showed that the formation of cyanogen chloride might be due to the reaction of humic substances with chloramine. ${ }^{14)}$ This result suggests that chloramination reaction with organic compounds often occurs during the chlorination process. Although the chlorination reactions of organic compounds were studied in detail, ${ }^{15-21)}$ little is known of the chloramination reaction in aqueous solution. This study was intended to investigate the mechanism of cyanogen chloride formation by the reaction of aromatic compounds with chloramine.

In this paper, we describe the pathway of cyanogen chloride formation from 1-naphthol and 4-phenylimidazole. 1-Naphthol and 4-phenylimidazole were selected as model compounds for phenol and histidine, respectively, in order to facilitate the isolation and detection of the reaction products.

\section{Experimental}

Proton nuclear magnetic resonance $\left({ }^{1} \mathrm{H}-\mathrm{NMR}\right)$ spectra were measured with tetramethylsilane (TMS) or 3- 
(trimethylsilyl)propionic acid- $d_{4}$ sodium salt $\left(\right.$ TSP- $d_{4}$ ) as an internal standard, with a JEOL GX270FT NMR spectrometer. Gas chromatography (GC) was performed on a Shimadzu 9A apparatus with a flame ionization detector using a glass column $(3 \mathrm{~mm}$ i.d. $\times 2 \mathrm{~m})$ packed with Tenax GC(60-80 mesh); injection temperature, $140 \mathrm{C}$; column temperature, $80^{\circ} \mathrm{C}$; carrier gas, $\mathrm{N}_{2} 40 \mathrm{ml} / \mathrm{min}$. GC-MS was performed on a JEOL DX-300 apparatus under the following conditions. (1) For the identification of $\mathrm{C}^{14} \mathrm{NCl}$ or $\mathrm{C}^{15} \mathrm{NCl}$ : column, glass column $(3 \mathrm{~mm}$ i.d. $\times 2 \mathrm{~m})$ packed with Tenax GC (60-80 mesh); carrier gas, He $20 \mathrm{ml} / \mathrm{min}$; column temperature, $85 \mathrm{C}$; injection temperature, $140 \mathrm{C}$; separator and ion source temperatures, $250^{\circ} \mathrm{C}$; ionizing voltage, $70 \mathrm{eV}$. (2) For the identification of reaction products: column, glass column $(3 \mathrm{~mm}$ i.d. $\times 2 \mathrm{~m}$ ) packed with $5 \%$ Silicone SE-30 on Chromosorb WAW (60-80 mesh); carrier gas, He $20 \mathrm{ml} / \mathrm{min}$; column temperatures; $90 \mathrm{C}$ (for benzonitrile) and $120 \mathrm{C}$ (for methyl benzoate and methyl benzoylformate); injection temperature, $200^{\circ} \mathrm{C}$; separator and ion source temperatures, $250 \mathrm{C}$; ionizing voltage, $70 \mathrm{eV}$.

Materials - $N$-Chloro-1,2-naphthoquinone 2-imine (2), 2-chloro-1,4-naphthoquinone (5), $o$-carboxycinnamonitrile (6) and phthalide-3-carboxylic acid (8) were synthesized by the methods of Friedlander and Reinhardt, ${ }^{22)}$ Cleve, ${ }^{23)}$ Beckmann and Liesche ${ }^{24)}$ and Gabriel, ${ }^{25)}$ respectively. Ammonium chloride- ${ }^{15} \mathrm{~N}(99$ atom $\%)$ was supplied by the British Oxygen Co., Ltd.

Synthesis of N,4-Dichloro-1,2-naphthoquinone 2-Imine (3)-A solution of stannous chloride $(5 \mathrm{~g})$ in $1 \mathrm{~N}$ hydrochloric acid $(10 \mathrm{ml})$ was added dropwise to a suspension of 4-chloro-2-nitroso-l-naphthol ${ }^{26)}(1 \mathrm{~g})$ in $\mathrm{con}^{-}$ centrated hydrochloric acid $(7 \mathrm{ml})$ in an ice bath. The mixture was stirred for $30 \mathrm{~min}$. The resultant precipitate, $2-$ amino-4-chloro-1-naphthol, was collected by filtration and used in the next reaction without further purification. 2 Amino-4-chloro-1-naphthol thus obtained was suspended in $6 \mathrm{~N}$ hydrochloric acid $(30 \mathrm{ml})$. Sodium hypochlorite solution was added dropwise to the suspension in an ice bath until the reaction was completed. The resultant precipitate was collected by filtration, washed with water, dried and purified by column chromatography on Kieselgel 60 using chloroform. The eluates were evaporated to dryness and the residue was recrystallized from $n$-hexane to give 3 as yellow needles, mp $150^{\circ} \mathrm{C}$. Anal. Calcd for $\mathrm{C}_{10} \mathrm{H}_{5} \mathrm{Cl}_{2} \mathrm{NO}: \mathrm{C}, 53.13 ; \mathrm{H}, 2.23 ; \mathrm{N}, 6.20$. Found: C, 53.16; H, 2.04; N, 6.30. ${ }^{1} \mathrm{H}-\mathrm{NMR}\left(270 \mathrm{MHz}, \mathrm{CDCl}_{3}\right) \delta: 7.47(1 \mathrm{H}, \mathrm{s}), 7.57-8.28(4 \mathrm{H}, \mathrm{m}) . \mathrm{MS} m / z: 225\left(\mathrm{M}^{+}\right)$.

Synthesis of $N$,2-Dichloro-1,4-naphthoquinone 4-Imine (4)_A solution of sodium nitrite $(0.8 \mathrm{~g})$ in water $(40 \mathrm{ml})$ was added dropwise to a stirred solution of 2-chloro-l-naphthol ${ }^{27)}(1.8 \mathrm{~g})$ in ethanol $(40 \mathrm{ml})$ and $4 \mathrm{~N}$ sulfuric acid $(40 \mathrm{ml})$ in an ice bath. The reaction mixture was diluted with water $(80 \mathrm{ml})$ and stirred for $30 \mathrm{~min}$. The resultant precipitate was collected by filtration, washed with water, dried and purified by column chromatography on Kieselgel 60 using benzene and ethyl acetate $(5: 1)$. The eluates were evaporated to dryness and the residue was recrystallized from benzene to give 2-chloro-4-nitroso-1-naphthol as pale yellow crystals, mp $185-186 \mathrm{C}$ (dec.). Anal. Calcd for $\mathrm{C}_{10} \mathrm{H}_{6} \mathrm{ClNO}_{2}: \mathrm{C}, 57.85 ; \mathrm{H}, 2.91 ; \mathrm{N}, 6.75$. Found: $\mathrm{C}, 57.92 ; \mathrm{H}, 2.75 ; \mathrm{N}, 6.61$. 2-Chloro-4-nitroso-1-naphthol (1 g) thus obtained was suspended in concentrated hydrochloric acid $(7 \mathrm{ml})$. A solution of stannous chloride $(5 \mathrm{~g})$ in $1 \mathrm{~N}$ hydrochloric acid $(10 \mathrm{ml})$ was added dropwise to the suspension in an ice bath. The mixture was stirred for $30 \mathrm{~min}$. The resultant precipitate, 4-amino-2-chloro-1-naphthol was collected by filtration and used in the next reaction without further purification. 4-Amino-2-chloro-1-naphthol thus obtained was suspended in $6 \mathrm{~N}$ hydrochloric acid $(30 \mathrm{ml})$. Sodium hypochlorite solution was added dropwise to the suspension in an ice bath until the reaction was completed. The resultant precipitate was collected by filtration, washed with water, dried and purified by column chromatography on Kieselgel 60 using chloroform. The eluates were evaporated to dryness and the residue was recrystallized from methanol to give 4 as yellow needles, mp $139-140 \mathrm{C}$. Anal. Calcd for $\mathrm{C}_{10} \mathrm{H}_{5} \mathrm{Cl}_{2} \mathrm{NO}: \mathrm{C}, 53.13 ; \mathrm{H}$, 2.23 ; $\mathrm{N}, 6.20$. Found: $\mathrm{C}, 53.12 ; \mathrm{H}, 2.05 ; \mathrm{N}, 6.07 .{ }^{1} \mathrm{H}-\mathrm{NMR}\left(270 \mathrm{MHz}, \mathrm{CDCl}_{3}\right) \delta: 8.24(1 \mathrm{H}, \mathrm{s}), 7.65-8.33(4 \mathrm{H}, \mathrm{m}) . \mathrm{MS}$ $m / z: 225\left(\mathrm{M}^{+}\right)$.

Synthesis of 3-Cyanochloromethylphthalide (7)-Sodium hypochlorite solution ( $10 \mathrm{mmol})$ was added to a solution of $6(173 \mathrm{mg}, 1 \mathrm{mmol})$ in $0.1 \mathrm{~N}$ sulfuric acid $(700 \mathrm{ml})$. The mixture was allowed to stand overnight at room temperature and extracted with chloroform. The chloroform layer was dried over anhydrous sodium sulfate and evaporated to dryness. The residue was chromatographed on a column of Kieselgel 60 using chloroform. The eluates were evaporated to dryness and the residue was recrystallized from chloroform- $\boldsymbol{n}$-hexane to give 7 as colorless needles, mp $106{ }^{\circ} \mathrm{C}$. Anal. Calcd for $\mathrm{C}_{10} \mathrm{H}_{6} \mathrm{ClNO}_{2}$ : C, 57.85; H, 2.91; N, 6.75. Found: C, 58.04; H, 2.88; N, 6.69. ${ }^{1} \mathrm{H}-$ $\operatorname{NMR}\left(270 \mathrm{MHz}, \mathrm{CDCl}_{3}\right) \delta: 4.94(1 \mathrm{H}, \mathrm{d}, J=4.8 \mathrm{~Hz}), 5.74(1 \mathrm{H}, \mathrm{d}, J=4.8 \mathrm{~Hz}), 7.65-8.10(4 \mathrm{H}, \mathrm{m}) . \mathrm{MS} m / z: 207\left(\mathrm{M}^{+}\right)$.

Formation of Cyanogen Chloride- - In a $120 \mathrm{ml}$ glass vial was placed $95 \mathrm{ml}$ of $0.3 \mathrm{M}$ phosphate buffer (pH 5.0 ) containing reaction material $(1,2,3,4,5,6,7,10,11,12$ or $13,10 \mu \mathrm{mol})$. Next, $2.0 \mathrm{ml}$ of $100 \mu \mathrm{mol} / \mathrm{ml}$ ammonium chloride aqueous solution and $3.0 \mathrm{ml}$ of $100 \mu \mathrm{mol} / \mathrm{ml}$ sodium hypochlorite aqueous solution were added, and the vial was sealed with a rubber cap. The reaction mixture was allowed to stand for $2 \mathrm{~h}$ at room temperature, then $1 \mathrm{ml}$ of the head space gas was injected into the GC apparatus. The cyanogen chloride standard solution was prepared from a mixture of $90 \mathrm{ml}$ of $0.3 \mathrm{M}$ phosphate buffer ( $\mathrm{pH} \mathrm{3.0),} 5 \mathrm{ml}$ of $0.5 \%$ chloramine-T aqueous solution and $5 \mathrm{ml}$ of $1 \mu \mathrm{mol} / \mathrm{ml}$ potassium cyanide aqueous solution.

Reaction of 1-Naphthol (1) with Chloramine-Sodium hypochlorite solution ( $15 \mathrm{mmol}$ ) was added to $400 \mathrm{ml}$ of $0.3 \mathrm{M}$ phosphate buffer ( $\mathrm{pH} 5.0$ ) containing ammonium chloride $(535 \mathrm{mg}, 10 \mathrm{mmol})$. This solution was immediately added to a stirred solution of $1(144 \mathrm{mg}, 1 \mathrm{mmol}$ ) in $100 \mathrm{ml}$ of $0.3 \mathrm{M}$ phosphate buffer (pH 5.0). The mixture was stirred for $3 \mathrm{~min}$ at room temperature and extracted with ether. The ether layer was dried over anhydrous sodium sulfate and 
evaporated to dryness. The residue was chromatographed on a column of Kieselgel 60 to give 4, 5, 3 and 2 successively from the fractions eluted with $n$-hexane-ethyl acetate $(10: 1)$. Compounds 4 and 5 were recrystallized from methanol and compounds 3 and 2 were recrystallized from $n$-hexane. These products $(2-5)$ were identified by comparison with authentic samples.

Reaction of 2 with Chloramine- Sodium hypochlorite solution $(6 \mathrm{mmol})$ was added to a stirred solution of 2 $(76 \mathrm{mg}, 0.4 \mathrm{mmol})$ and ammonium chloride $(214 \mathrm{mg}, 4 \mathrm{mmol}$ ) in $500 \mathrm{ml}$ of $0.3 \mathrm{M}$ phosphate buffer (pH 5.0). The reaction mixture was allowed to stand for $1 \mathrm{~h}$ at room temperature, acidified to $\mathrm{pH} 2$ with phosphoric acid and extracted with ethyl acetate. The ethyl acetate layer was dried over anhydrous sodium sulfate and evaporated to dryness. The residue was chromatographed on a column of Kieselgel 60 using benzene-methanol-acetic acid $(10: 0.1: 0.1)$. The eluates were evaporated to dryness and the residue was recrystallized from benzene to give 6 . The product (6) was identified by comparison with an authentic sample.

Reaction of 6 with Chloramine - Sodium hypochlorite solution $(45 \mathrm{mmol})$ was added to a stirred solution of 6 $(173 \mathrm{mg}, 1 \mathrm{mmol})$ and ammonium chloride $(1605 \mathrm{mg}, 30 \mathrm{mmol})$ in 1.51 of $0.05 \mathrm{M}$ phosphate buffer (pH 5.0). The reaction mixture was allowed to stand for $2 \mathrm{~h}$ at room temperature, concentrated to about $150 \mathrm{ml}$, acidified to $\mathrm{pH} 2$ with phosphoric acid and extracted with ethyl acetate. The ethyl acetate layer was dried over anhydrous sodium sulfate and evaporated to dryness. The residue was chromatographed on a column of Kieselgel 60 . The first fraction eluted with chloroform gave 7 , which was recrystallized from chloroform- $n$-hexane. The second fraction eluted with benzene-dioxane-acetic acid $(10: 1: 1)$ gave 8 , which was recrystallized from benzene. The products $(7$ and 8$)$ were identified by comparison with authentic samples.

Identification of $\mathbf{C}^{14} \mathrm{NCl}$ or $\mathbf{C}^{15} \mathrm{NCl}-\mathrm{A}$ mixture of $83.5 \mathrm{ml}$ of $0.3 \mathrm{M}$ phosphate buffer (pH 5.0 ), $3 \mathrm{ml}$ of $10 \mu \mathrm{mol} / \mathrm{ml} 4$-methylimidazole (11) or 2-methylimidazole (13), $4.5 \mathrm{ml}$ of $100 \mu \mathrm{mol} / \mathrm{ml}$ ammonium chloride- ${ }^{15} \mathrm{~N}$ aqueous solution and $9 \mathrm{ml}$ of $100 \mu \mathrm{mol} / \mathrm{ml}$ sodium hypochlorite aqueous solution in a $120 \mathrm{ml}$ glass vial with a rubber cap was allowed to stand for $2 \mathrm{~h}$ at room temperature and $1 \mathrm{ml}$ of the head space gas was injected into the GC-MS apparatus.

Formation of Benzonitrile (14), Benzoylformic Acid (22) and Benzoic Acid (23)—4-Phenylimidazole (10,58 mg, $0.4 \mathrm{mmol}$ ) and ammonium chloride $(321 \mathrm{mg}, 6 \mathrm{mmol}$ ) were dissolved in $200 \mathrm{ml}$ of $0.3 \mathrm{M}$ phosphate buffer (pH 5.0 ). Sodium hypochlorite solution $(12 \mathrm{mmol})$ was added to the solution and the reaction mixture was allowed to stand for $1 \mathrm{~h}$ at room temperature. A half of the reaction mixture was extracted with $10 \mathrm{ml}$ of chloroform. The chloroform layer was dried over anhydrous sodium sulfate, and then subjected to GC-MS analysis for the identification of benzonitrile (14). The remaining reaction mixture was acidified to $\mathrm{pH} 2$ with phosphoric acid and extracted with $30 \mathrm{ml}$ of ethyl acetate. The ethyl acetate layer was dried over anhydrous sodium sulfate and evaporated to dryness. The residue was treated with ethereal diazomethane. The resulting solution was concentrated, and the residue was dissolved in $10 \mathrm{ml}$ of chloroform. The chloroform solution was subjected to GC-MS analysis for the identification of methyl benzoylformate and methyl benzoate.

Formation of 5-Acetylamino-4-phenylimidazole (15)_- Sodium hypochlorite solution (64 mmol) was added to $400 \mathrm{ml}$ of $0.3 \mathrm{M}$ phosphate buffer ( $\mathrm{pH} 5.0)$ containing ammonium chloride $(1.71 \mathrm{~g}, 32 \mathrm{mmol})$. This solution was immediately added to a stirred solution of 4-phenylimidazole (10) $(576 \mathrm{mg}, 4 \mathrm{mmol})$ in $600 \mathrm{ml}$ of $0.3 \mathrm{M}$ phosphate buffer ( $\mathrm{pH} \mathrm{5.0)}$. The mixture was stirred for $3 \mathrm{~min}$ at room temperature and extracted with $150 \mathrm{ml}$ of ethyl acetate. The ethyl acetate layer was dried over anhydrous sodium sulfate, then acetic anhydride $(40 \mathrm{ml})$, zinc powder $(6 \mathrm{~g})$, acetic acid $(4 \mathrm{ml})$ and sodium acetate hydrate $(3 \mathrm{~g})$ were added. The mixture was heated at about $80 \mathrm{C}$ for $1 \mathrm{~h}$ under stirring, then cooled to room temperature and filtered. The filtrate was concentrated and the residue was suspended in water $(200 \mathrm{ml})$ and extracted with ethyl acetate $(100 \mathrm{ml})$. The ethyl acetate layer was dried over anhydrous sodium sulfate and concentrated. The residue was chromatographed on a column of Kieselgel 60 using chloroformmethanol $(10: 3)$. The eluates were concentrated and the residue was chromatographed again on a column of Kieselgel 60 using benzene-methanol $(10: 3)$. The eluates were concentrated and the residue was crystallized from methanol-benzene to give 5-acetylamino-4-phenylimidazole (15) as colorless needles, mp $251-252^{\circ} \mathrm{C} .{ }^{1} \mathrm{H}-\mathrm{NMR}$ $\left(270 \mathrm{MHz}, \mathrm{DCl}+\mathrm{D}_{2} \mathrm{O}\right) \delta: 2.25\left(3 \mathrm{H}, \mathrm{s},-\mathrm{COCH}_{3}\right), 7.55-7.70(5 \mathrm{H}, \mathrm{m}, \mathrm{ArH}), 8.73(1 \mathrm{H}, \mathrm{s}, \mathrm{C}-2-\mathrm{H}) . \mathrm{MS} m / z: 201\left(\mathrm{M}^{+}\right)$. High-resolution MS $m / z: 201.0901$ Calcd for $\mathrm{C}_{11} \mathrm{H}_{11} \mathrm{~N}_{3} \mathrm{O}\left(\mathrm{M}^{+}\right)$. Found: $m / z 201.0906$.

\section{Results and Discussion}

\section{Pathway of Cyanogen Chloride Formation from 1-Naphthol (1)}

The reaction of 1-naphthol (1) with chloramine gave four products, which were identified as $N$-chloro-1,2-naphthoquinone 2-imine (2), $N$,4-dichloro-1,2-naphthoquinone 2-imine (3), $N, 2$-dichloro-1,4-naphthoquinone 4-imine (4), and 2-chloro-1,4-naphthoquinone (5). These four products reacted with chloramine to give cyanogen chloride, the yields of which are shown in Fig. 1. Of these compounds, 2 and $\mathbf{3}$ gave greater amounts of cyanogen chloride than 1 did. Therefore, $\mathbf{2}$ and $\mathbf{3}$ were considered to be intermediates in the reaction. 


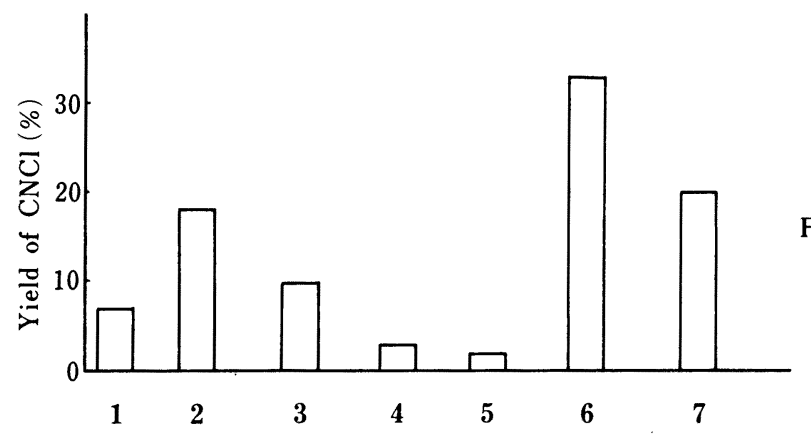

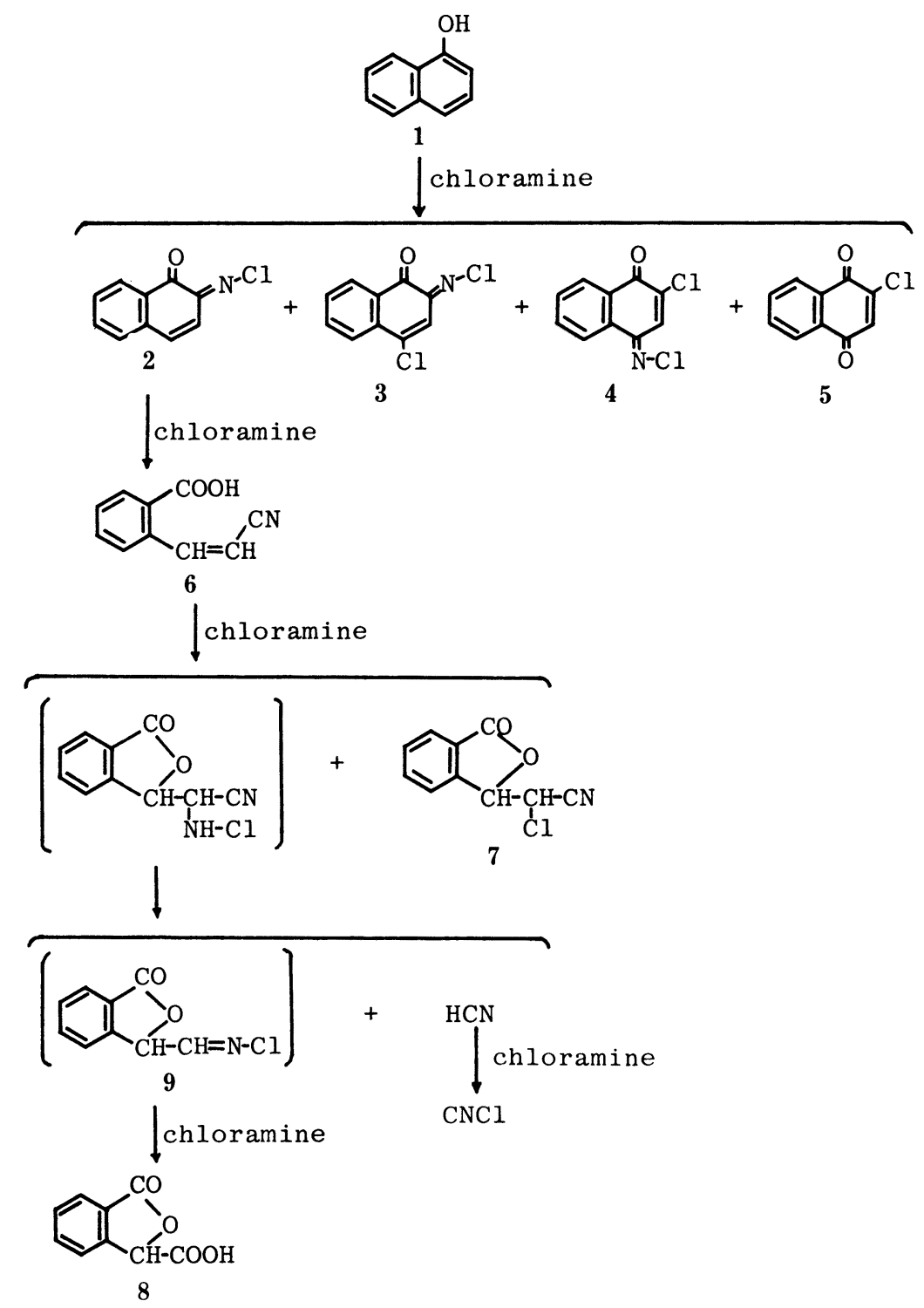

ig. 1. Yields of Cyanogen Chloride ( $\mu \mathrm{mol}$ of Cyanogen Chloride $/ \mu \mathrm{mol}$ of Substrate) from Compounds 1-7

Compounds $1-7,10 \mu \mathrm{mol} ; \quad \mathrm{NH}_{4} \mathrm{Cl}, 200 \mu \mathrm{mol}$; $\mathrm{NaClO}$ (aqueous), $300 \mu \mathrm{mol}$; phosphate buffer ( $\mathrm{pH}$ 5.0), $100 \mathrm{ml}$.

Chart 1 


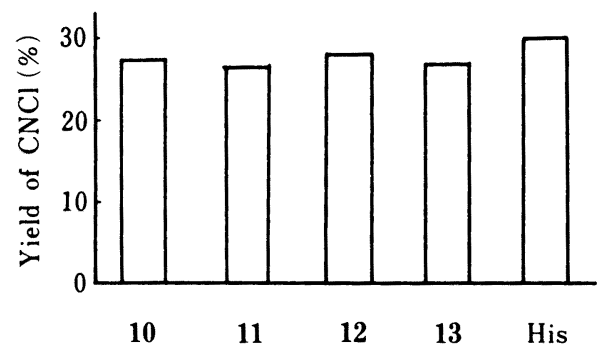

Fig. 2. Yields of Cyanogen Chloride ( $\mu \mathrm{mol}$ of

TABle I. Ratios of $\mathrm{C}^{14} \mathrm{NCl}$ and $\mathrm{C}^{15} \mathrm{NCl}$ to Total Cyanogen Chloride

\begin{tabular}{ccc}
\hline \hline Material & $\mathrm{C}^{14} \mathrm{NCl}(\%)$ & $\mathrm{C}^{15} \mathrm{NCl}(\%)$ \\
\hline 4-Methylimidazole (11) & 93 & 7 \\
2-Methylimidazole (13) & 90 & 10 \\
\hline
\end{tabular}

Cyanogen Chloride $/ \mu \mathrm{mol}$ of Substrate) from Imidazole Derivatives

Imidazole derivatives, $10 \mu \mathrm{mol} ; \mathrm{NH}_{4} \mathrm{Cl}, 150 \mu \mathrm{mol}$; $\mathrm{NaClO}$ (aqueous), $300 \mu \mathrm{mol}$; phosphate buffer ( $\mathrm{pH}$ $5.0), 100 \mathrm{ml}$.

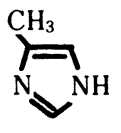

11<smiles>Cc1ncc[nH]1</smiles>

13

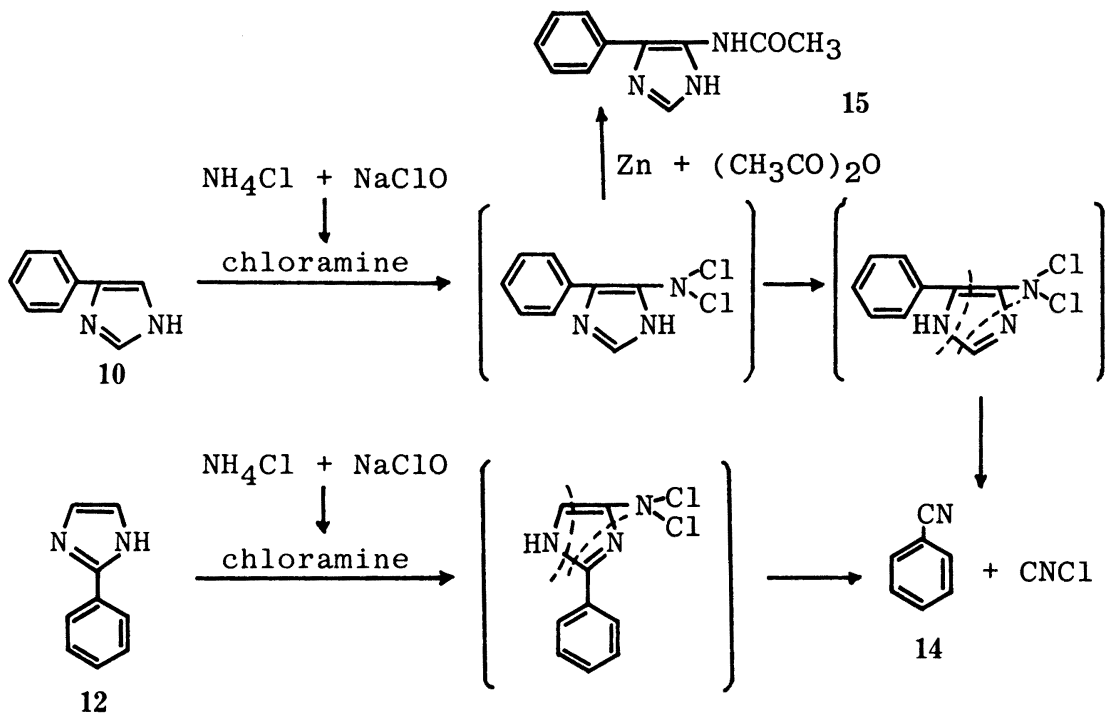

Chart 2

Further, compound 2, which gave the highest yield of cyanogen chloride, reacted with chloramine to give $o$-carboxycinnamonitrile (6). The yield of cyanogen chloride from 6 was higher than that from 2 (Fig. 1). Therefore, it was concluded that 6 was an intermediate in the next reaction step.

Further, the reaction of 6 with chloramine resulted in 3-cyanochloromethylphthalide (7) and phthalide-3-carboxylic acid (8). The yield of cyanogen chloride from 7 was lower than that from 6 (Fig. 1). Therefore, 7 was not a main intermediate in the reaction.

On the basis of these results, the formation of cyanogen chloride from 1-naphthol (1) is considered to occur through the following steps; first, the formation of 2 , second, the conversion of $\mathbf{2}$ to $\mathbf{6}$, third, the chloramination of $\mathbf{6}$, then the decomposition into cyanogen 


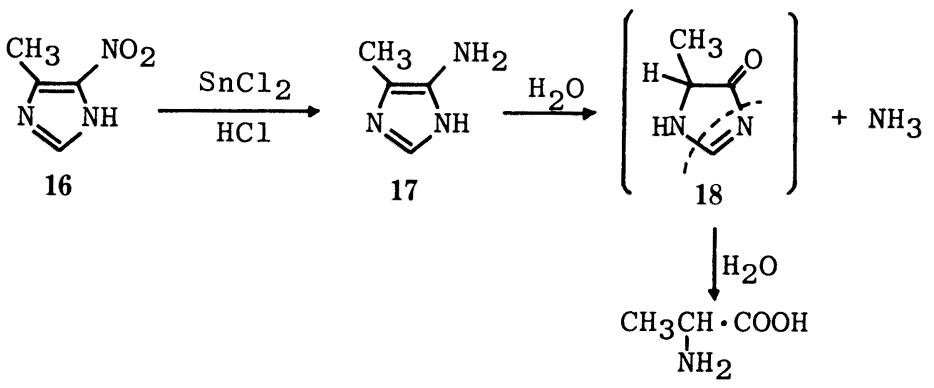

19

Chart 3

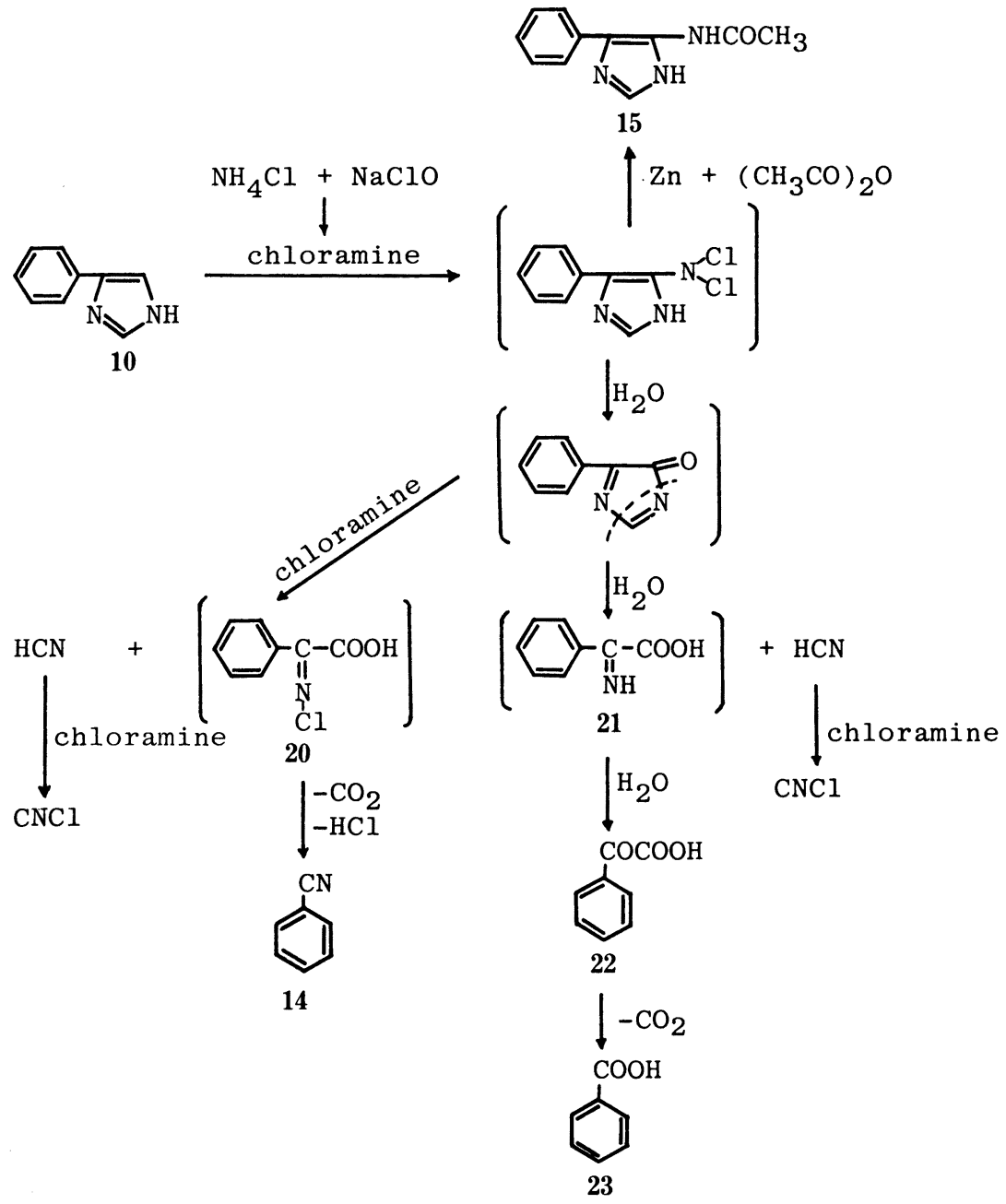

Chart 4

chloride and 9. Compound 9 was finally converted to 8 (Chart 1).

Pathway of Cyanogen Chloride Formation from 4-Phenylimidazole (10)

4-Methylimidazole (11), 2-phenylimidazole (12) and 2-methylimidazole (13) besides 4phenylimidazole (10) were reacted with chloramine in order to elucidate the pathway of 


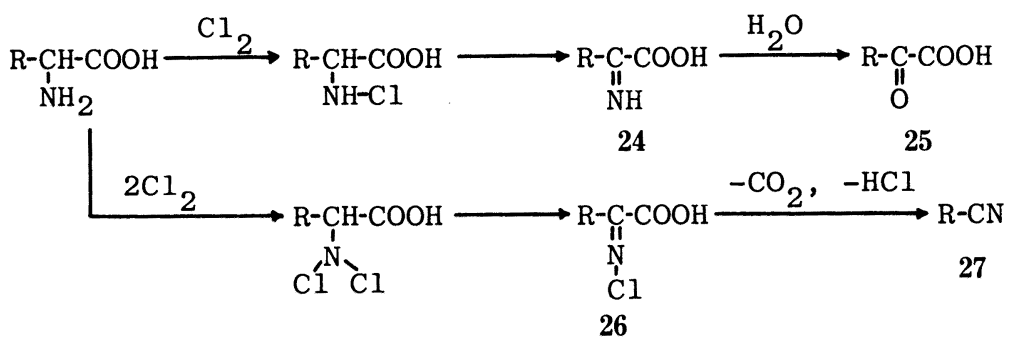

Chart 5

cyanogen chloride formation. These four imidazole derivatives gave cyanogen chloride, as did histidine (His). The yields of cyanogen chloride are shown in Fig. 2.

Then, the reactions of 4-methylimidazole (11) and 2-methylimidazole (13) with $\left[{ }^{15} \mathrm{~N}\right]-$ chloramine were carried out in order to clarify the origin of the nitrogen atom of cyanogen chloride (from methylimidazole or from chloramine). The resulting $\mathrm{C}^{14} \mathrm{NCl}$ and $\mathrm{C}^{15} \mathrm{NCl}$ were determined by GC-MS. The results are shown in Table I. In both cases, the nitrogen atom of cyanogen chloride originated mostly from the imidazole ring.

Further, it was found that the reaction of 4-phenylimidazole (10) with chloramine gave benzonitrile (14). 2-Phenylimidazole (12) also gave the same result. In addition, when the ethyl acetate extract of the reaction mixture of 4-phenylimidazole (10) with chloramine was treated with zinc powder and acetic anhydride, 5-acetylamino-4-phenylimidazole (15) was obtained; this shows that chloramine attacks the C-5 position of the imidazole ring (Chart 2).

Fargher ${ }^{28)}$ reported that the reduction of 4-methyl-5-nitroimidazole (16) gave alanine (19) and ammonia via 5-amino-4-methylimidazole (17) and 4,5-dihydro-5-methyl-4imidazolone (18) (Chart 3); this shows the instability of 5-aminoimidazole derivatives.

These results indicate that chloramination occurred at the C-5 position of the imidazole ring and then the ring was cleaved along the dotted lines shown in Chart 2.

Besides the products mentioned above, benzoylformic acid (22) and benzoic acid (23) were also obtained by the reaction of 4-phenylimidazole (10) with chloramine.

On the basis of these results, the pathway of cyanogen chloride formation from 4phenylimidazole (10) is concluded to be as shown in Chart 4; first, chloramination at the C-5 position of 4-phenylimidazole (10), second, the cleavage of the imidazole ring and third, the formation of cyanogen chloride, benzonitrile (14), benzoylformic acid (22) and benzoic acid (23). Benzonitrile (14) and benzoylformic acid (22) might be formed via imino intermediates $(20,21)$; this could be explained in terms of the reaction of $\alpha$-amino acid with chlorine ${ }^{29-31)}$ in which $\alpha$-keto acid $(25)$ and nitrile are formed via imino intermediates $(24,26)($ Chart 5$)$.

Acknowledgements The authors are grateful to Professor Emeritus Shun-ichi Yamada and Professor Masaaki Hirobe, Faculty of Pharmaceutical Sciences, University of Tokyo, for their encouragement and valuable suggestions throughout this work.

\section{References}

1) Part IX: N. Maeda, T. Ohya, K. Nojima and S. Kanno, Chemosphere, 16, 2249 (1987).

2) R. L. Jolley and J. H. Carpenter, "Water Chlorination: Environmental Impact and Health Effects," Vol. 4, Ann Arbor Science, Ann Arbor, 1983, p. 3.

3) K. L. Shih and J. Lederberg, Science, 192, 1141 (1976).

4) "Standard Methods for the Examination of Water and Wastewater," 14th edition, American Public Health Association, Washington, 1975, p. 309.

5) R. F. Christman, J. D. Johnson, J. R. Hass, F. K. Pfaender, W. T. Liao, D. L. Norwood and H. J. Alexander, 
"Water Chlorination: Environmental Impact and Health Effects," Vol. 2, Ann Arbor Sciènce, Ann Arbor, 1978, p. 15.

6) R. F. Christman and M. Ghassemi, J. Am. Water Works Assoc., 58, 723 (1966).

7) M. Schnitzer and S. U. Khan, "Humic Substances in the Environment," Marcel Dekker, New York, 1972.

8) J. J. Rook, Environ. Sci. Technol., 11, 478 (1977).

9) J. L. Burleson, G. R. Peyton and W. H. Glaze, Environ. Sci. Technol., 14, 1354 (1980).

10) S. Kanno, K. Nojima and T. Ohya, Chemosphere, 11, 663 (1982).

11) S. Kanno, K. Nojima and T. Ohya, Chemosphere, 11, 669 (1982).

12) S. Kanno and T. Ohya, Chem. Pharm. Bull., 32, 348 (1984).

13) T. Ohya and S. Kanno, Chem. Pharm. Bull., 32, 280 (1984).

14) T. Ohya and S. Kanno, Chemosphere, 14, 1717 (1985).

15) H. Hayatsu, S. K. Pan and T. Ukita, Chem. Pharm. Bull., 19, 2189 (1971).

16) J. G. Smith, S. F. Lee and A. Netzer, Water Res., 10, 985 (1976).

17) S. Onodera, J. Kato, Y. Kamonzeki and S. Ishikura, Eisei Kagaku, 23, 331 (1977).

18) D. L. Norwood, J. D. Johnson, R. F. Christman, J. R. Hass and M. J. Bobenrieth, Environ. Sci. Technol., 14, 187 (1980).

19) M. Tomita, H. Manabe, K. Honma and A. Hamada, Eisei Kagaku, 28, 21 (1982).

20) S. D. Boyce and J. F. Hornig, Environ. Sci. Technol., 17, 202 (1983).

21) E. W. B. de Leer and C. Erkelens, The Science of the Total Environment, 47, 211 (1985).

22) P. Friedlander and O. Reinhardt, Chem. Ber., 27, 239 (1894).

23) P. T. Cleve, Chem. Ber., 21, 892 (1888).

24) E. Beckmann and O. Liesche, Chem. Ber., 56, 1 (1923).

25) S. Gabriel, Chem. Ber., 40, 78 (1907).

26) T. Korenaga, S. Motomizu and K. Toei, Nippon Kagaku Kaishi, 1972, 2445.

27) D. Ginsburg, J. Am. Chem. Soc., 73, 2723 (1951).

28) R. G. Fargher, J. Chem. Soc., 117, 668 (1920).

29) S. W. Fox and M. W. Bullock, J. Am. Chem. Soc., 73, 2754 (1951).

30) H. D. Dakin, Biochem. J., 10, 319 (1916).

31) T. I. Bieber and M. L. Trehy, "Water Chlorination: Environmental Impact and Health Effects," Vol. 4, Ann Arbor Science, Ann Arbor, 1983, p. 85. 